\title{
THE EFFECT OF WELFARE, SELF-EFFICACY AND WORK ENVIRONMENT ON EMPLOYEE PERFORMANCE AND ORGANIZATIONAL PERFORMANCE : STUDY IN ACEH FINANCIAL MANAGEMENT AGENCY
}

\author{
Jonny Rahmadi, Nasir and Sofyan Idris \\ Department of Management, Universitas Syiah Kuala, Indonesia \\ http://doi.org/10.35409/IJBMER.2019.2432
}

\begin{abstract}
This study is to determine the effect of welfare, self-efficacy and work environment on employee performance and organizational performance. The object of this study is the Aceh Financial Management Agency and the population is its employees as much as 127 people. The sample is taken with a census method that says the number of sample is equal to population, so there will be 127 people as a sample. Data analysis method used in this research is the structural equation modeling (SEM) that is processed by Amos software. The results of causality test in the study prove that welfare has a positive and significant effect on the employee performance, self efficacy has a positive and significant effect on employee performance, work environment has a positive and significant effect on employee performance, employee performance has a positive and significant effect on organizational performance, welfare has a positive and significant effect on organizational performance, self efficacy has a positive and significant effect on organizational performance, and work environment has a positive and significant effect on organizational performance. This research contribute to academic and practical managers that can be set as a reference to formulate both new research model and policies. For academic, this causality tests result is the update of the premises to streghten the further research, and enrich the realm of knowledge. For managers especially related managers this is the evaluation result for management that can be used for re-regulating the rules in their management to find out the solution for the lack of performance. The limitation in this study lies in the number of variables, and object.
\end{abstract}

Keyword: welfare, self efficacy, work environment, employee performance and organizational performance.

\section{INTRODUCTION}

Human resources are central figures in the organization. In order for the management activities of the Aceh Financial Management Agency to run well, it must have human resources who are knowledgeable and highly skilled and try to manage the organization as optimally as possible so that organizational performance can improve. The performance is the work of both the quality and quantity achieved in accordance with the duties and responsibilities. Based on the observations that the author did to the Aceh Financial Management Agency, the performance of the organization still does not show like the expectation of their leader. 


\section{International Journal of Business Management and Economic Review}

Vol. 2, No. 06; 2019

ISSN: 2581-4664

This can be seen from the low level of welfare of the organization's employees. The level of welfare that is expected and accepted by employees has not been in accordance with the duties and responsibilities that must be carried out by employees. The level of welfare of employees is closely related to the amount of salary or allowances received by employees each month. In addition, the performance of employees in the Aceh Financial Management Agency is also caused by the existence ofself efficacy factors which are also not able to make a real contribution to improving the performance of the office of the Aceh Financial Management Agency. While other factors that influence the improvement of employee performance and also the performance of the organization are the work environment that exists in the Aceh Financial Management Agency.

Phenomenon related to employee performance can be seen from several indicators, namely the ability to develop work plans that have not been realized, employees have not been able to realize the work plans that have been made, there are still many employees who have not been able to carry out orders from superiors in completing the work that has been determined, and not yet able provide satisfying services to every community. The low achievement of organizational performance is caused by several factors, but in this study the authors limit only to three variables, namely the level of welfare,self efficacy and work environment.

The level of welfare of employees in the Aceh Financial Management Agency is still relatively not commensurate with the sacrifices that have been made by employees, and there is also a gap between employees in this regard the level of welfare obtained, this can be seen from some employees who have a high level of welfare due to occupying certain positions and employees whose welfare level is still low because they do not have a position so that the level of welfare obtained is still relatively low. Factors related to employee welfare, the Aceh Financial Management Agency has made various efforts to improve the prosperity of its employees, for example by paying attention to providing sufficient salaries for the monthly living needs of employees, providing benefits and providing work performance benefits. However, in reality there is still dissatisfaction which is reflected in the attitudes and behavior of employees who demand that the work be carried out in accordance with their competence.

While the self-efficacy factor in the Aceh Financial Management Agency is not so good, self-efficacy is expressed as a person's belief that he can carry out a task at a certain level. (Silvia, Maria Luisa, Francesco, \& Michele, 2010). According to (Silvia et al., 2010), self efficacy is a person's belief that he can master the situation and produce positive outcomes. Regarding self efficacy, the phenomenon found that there are low self-confidence barriers from some employees because they cannot master the situation in carrying out their duties in accordance with the existing Standard Operating Procedure (SOP), inadequate mastery of applicable tax regulations that are frequent and numerous changes from the rules or provisions of the taxation itself and there are several employees whose experience / tenure is still minimal.

While the work environment problem also has an effect on improving the performance of the Aceh Financial Management Agency, this is because the existence of a good and comfortable work environment will have a positive impact on improving the performance of the Aceh Financial Management Agency. But in reality the work environment provided by employees in achieving organizational goals is still relatively low, this can be seen from the non-physical environment in the form of relationships between co-workers and the physical work environment which includes cleanliness of the room, work facilities and lighting as well as the level of office 


\section{International Journal of Business Management and Economic Review}

Vol. 2, No. 06; 2019

ISSN: 2581-4664

noise due to being close with the highway, thus impacting the comfort of office space.

\section{LITERATURE REVIEW}

\section{Organizational Performance}

Organizational performance is an indicator of achievement levels that can be achieved and reflects the success of an organization, as well as the results achieved from the behavior of organizational members. Performance can also be said as a result (output) of a particular process carried out by all components of the organization against certain sources used (input). Furthermore, performance is also the result of a series of process activities carried out to achieve certain organizational goals. For an organization, performance is the result of cooperative activities among members or organizational components in order to realize organizational goals. Organizational performance is the totality of work achieved by an organization. The achievement of organizational goal means that, the performance of an organization can be seen from the extent to which the organization can achieve goals based on the goals that have been set beforehand. (Sujardi, 2009)

In connection with the difficulties that occur in measuring the performance of public organizations stated by (Dwiyanto, 2012), the difficulty in measuring the performance of public service organizations arises partly because the goals and mission of public organizations are often not only vague but also multidimensional. Public organizations have stakeholders that are far more complex than private organizations. Stakeholders from public organizations often have interests that clash with one another, as a result the size of the performance of public organizations in the eyes of stakeholders also varies.

\section{Employee Performance}

The success of an organization is influenced by the performance (job performance) of employees, for that every company will try to improve the performance of its employees in achieving organizational goals that have been set. Organizational culture that grows and is well maintained will be able to spur organizations towards better development. On the other hand, the ability of leaders to move and empower employees will affect performance.

Employee performance refers to someone's achievement measured by standards and criteria set by the company. Management to achieve high human resource performance is intended to improve the company as a whole (Flippo, 1997). According to (Waldman \& Siegel, 2008) performance is a combination of behavior with the achievement of what is expected and choices or part of the requirements of the tasks that exist in each individual in the organization. Whereas according to (Rivai \& Sagala, 2014) performance can be defined as work results in quality and quantity that can be achieved by an employee in carrying out tasks in accordance with the responsibilities assigned to him. (Timpe, 2012) said that performance is the result of an employee's work over a certain period compared to various possibilities, such as standards, targets / targets / criteria that have been determined in advance and mutually agreed upon.

Performance is the result or level of success of a person as a whole during a certain period in carrying out tasks compared to the standard of work, targets or targets or criteria that have been predetermined and mutually agreed upon (Rivai \& Sagala, 2014). Furthermore Rivai stated that performance is not independent but related to job satisfaction and compensation, influenced 


\section{International Journal of Business Management and Economic Review}

Vol. 2, No. 06; 2019

ISSN: 2581-4664

by individual skills, abilities and characteristics. In other words, performance is determined by ability, desire and environment. Therefore, in order to have good performance, one must have a high desire to work and know the work and can be improved if there is a match between work and ability.

\section{Welfare}

According to (Hasibuan, 2007). Employee welfare is a recipient of complementary (material and non-material) services provided based on wisdom. The goal is to maintain and improve the physical and mental conditions of employees so that their productivity increases.

Meanwhile, according to (Hariandja \& Hardiwati, 2002), employee benefit and welfare are not based on employee performance, but are based on their membership as part of the organization, as well as employee as a human being who has many needs in order to be able to run his life normally and can work more good."

According to (Hariandja \& Hardiwati, 2002), welfare is the overall remuneration received by employee as a result of the execution of work in the organization in the form of money or otherwise, which can be in the form of salary wages, bonuses, incentives, and holiday allowances, food money, money leave, etc.Based on some of the opinions above it can be concluded that employee welfare is an indirect remuneration or an extra salary or wage given to employees and the gift is not based on employee performance but is based on membership as part of the organization that is useful to meet employee needs beyond wages / salaries .

\section{Self Efficacy}

Self efficacy is expressed as a person's belief that he can carry out a task at a certain level. (Bandura, 1993), states that self-efficacy is a person's belief that he can master the situation and produce positive outcomes. (Bandura, 1993), states that the measurement of self efficacy owned by someone refers to three dimensions, namely:

a. Active mastery, that is, a level of a person believes in an effort or action he can take in completing a job. Consists of indicators of job mastery, response to the work given, responsibility for work.

b. Experience, is a confidence in a person that he can manifest in achieving certain performance. It consists of indicators of the ability to predict work, the ability to overcome threats, and past experiences that support work.

c. Persuasion, defined as freedom from the form of self-efficacy that a person has to use in different situations. Consists of an indicator of confidence in completing the work on time, confidence in completing the work in accordance with the procedure.

Meanwhile, according to (Bandura, 1993), self efficacy is a situation where a person believes that they can control the results of the effort that has been done.

\section{Work Environment}

The work environment is one of the important factors in creating employee performance. Because the work environment has a direct influence on employees in completing work which will ultimately improve organizational performance. A working environment condition is said to be good if employees can carry out activities optimally, healthily, safely and comfortably. Therefore the creation of a good work environment will greatly determine the success of 


\section{International Journal of Business Management and Economic Review}

Vol. 2, No. 06; 2019

ISSN: 2581-4664

achieving organizational goals. Conversely, if the work environment is not good, it can reduce motivation and morale and ultimately can reduce employee performance.

The condition and atmosphere of a good work environment will be created by the organization's organization properly and correctly as stated by (Robins \& Coulter, 2012) that a good working atmosphere is produced, especially in well-organized organizations, while an unfavorable working atmosphere is caused by many organizations which is not well arranged. From these opinions it can be explained that the creation of a work atmosphere is strongly influenced by the organizational structure in the organization.

According to Artoyo (Nawawi, 2011) good management thinks of a good and pleasant work environment because it is needed by the workforce. The environment is thought to have a strong influence on the formation of employee behavior. The work environment has an important position in an integrated management control environment whose elements are labor, work tools, working conditions, organizational leadership and policy patterns.

\section{Research Hypothesis}

From the discussion above, it formulates the hypothesis as follows.

$\mathrm{H} 1$ : welfare has a significant effect on the employee performance,

$\mathrm{H} 2$ : self efficacy has a significant effect on employee performance,

H3 : work environment has a significant effect on employee performance,

H4 : employee performance has a significant effect on organizational performance,

H5 : welfare has a significant effect on organizational performance,

H6 : self efficacy has a significant effect on organizational performance, and,

$\mathrm{H} 7$ : work environment has a significant effect on organizational performance.

\section{METHOD}

This research is a causality test of the variables that integrates reseach models from the previous. The object of this study is the Aceh Financial Management Agency andthe Population is its employees as much as 127 people. The sample is taken with a census method that says the number of sample is equal to population, so there will be 127 people as a sample. Data analysis method used in this research is the structural equation modeling (SEM) that is processed by Amos software. The SEM equation model is a set of statistical techniques that enable the testing of a relatively complex set of relationships simultaneously (Ferdinand, 2002).SEM is able to incorporate latent variables into the analysis. Latent variables are unobserved concepts that are observed with observed or measurable variables obtained by respondents through data collection methods (survey, test, observation) and are often called manifest variables (Ghozali, 2018).

\section{RESULT}

The full model analysis of Structural Equation Model (SEM) is provided after analyzing the level of dimensionality of the latent variable forming indicators tested by confirmatory factor analysis. In the SEM full model stage the anaysis is carried out by testing the suitability and statistical tests. The research are shown in Figure 1. 


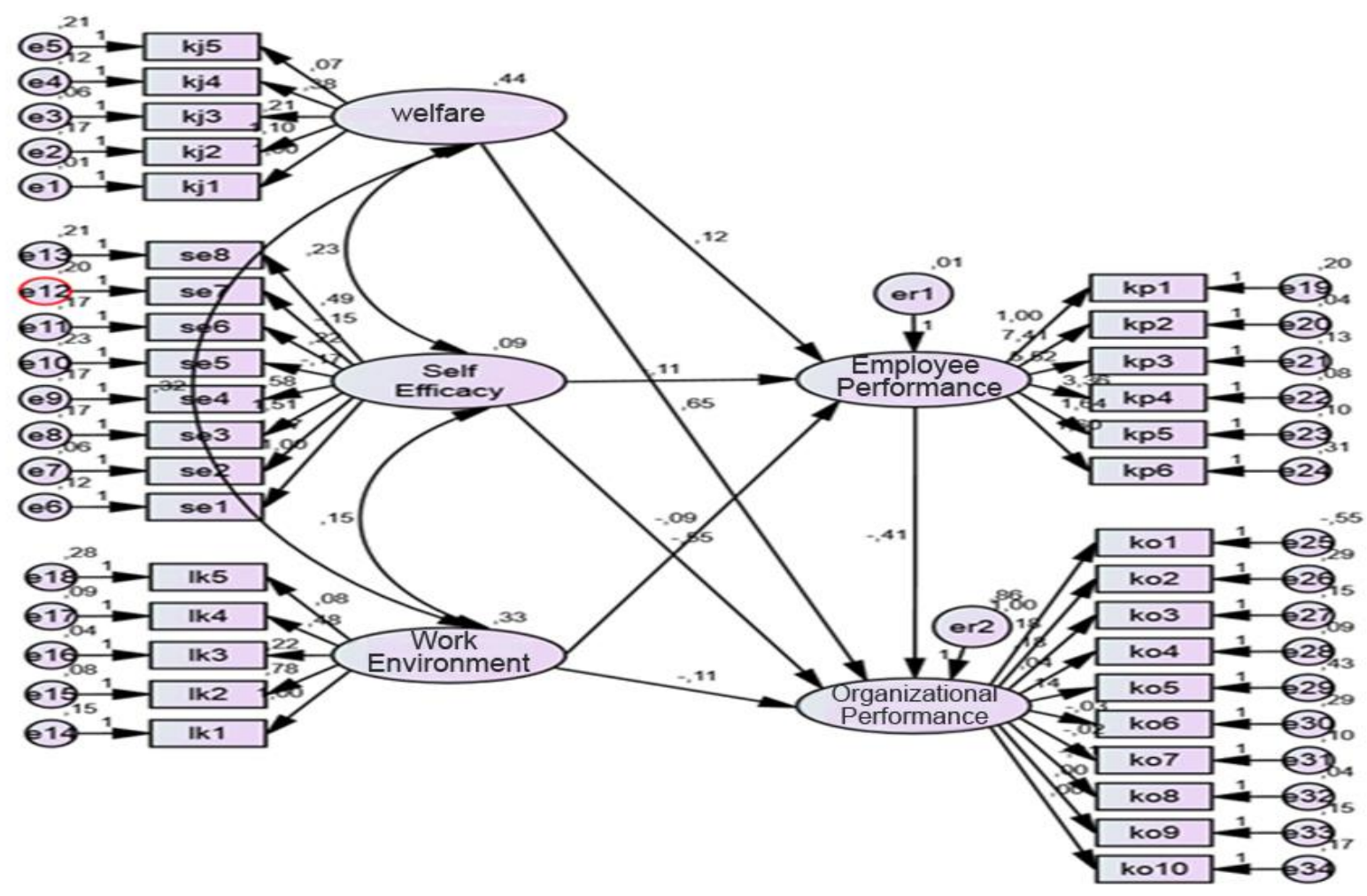

Figure. 1. Structural Equation Model (SEM) Test Results

\section{H1 is accepted :the effect of welfare on employee performance}

Estimated parameter values for testing the effect of welfare on employee performance shows the CR value of 4.298 and with a probability of 0.000 . The two values obtained meet the requirements for $\mathrm{H} 1$ acceptance, the $\mathrm{CR}$ value is 4.298 which is greater than 1.97 and a probability smaller than 0.05 . Thus it explains that welfare influences employee performance in the Aceh Financial Management Agency.

\section{$\mathrm{H} 2$ is accepted : the effect ofself efficacy on employee performance}

Estimated value for testing the effect ofself efficacy on employee performance shows CR value of 6.432 and with a probability of 0.000 . Both values meet the requirements for $\mathrm{H} 2$ acceptance, that is the CR value of 6.432 which is greater than 1.97 and a probability smaller than 0.05. Thus it figures thatself efficacy influences employee performance in the Aceh Financial Management Agency.

\section{H3 is accepted : the effect of work environment on employee performance}

Estimated parameter values for testing the effect of the work environment on employee 


\section{International Journal of Business Management and Economic Review}

Vol. 2, No. 06; 2019

ISSN: 2581-4664

performance shows the $\mathrm{CR}$ value of 6.713 and with a probability of 0.000 . Both values meet the requirements for $\mathrm{H} 3$ acceptance, namely the $\mathrm{CR}$ value of 6.713 which is greater than 1.97 and a probability smaller than 0.05 . Thus it describes that work environment influences employee performance in the Aceh Financial Management Agency.

\section{H4 is accepted : the effect of employee performance on organizational performance}

The effect of employee performance on organizational performance obtained CR value of 6.579 with a probability of 0.0001 . Both values meet the requirements for $\mathrm{H} 4$ acceptance, namely the CR value of 6.579 which is greater than 1.97 and a probability smaller than 0.05 . Thus it indicates that employee performance influences organizational performance in the Aceh Financial Management Agency

\section{H5 is accepted : the effect of welfare on organizational performance}

Estimated parameter values for testing the influence of welfare on organizational performance shows the CR value of 7.752 and with a probability of 0.000 . Both values are obtained to meet the requirements for H5 acceptance, namely the CR value of 7.752 which is greater than 1.97 and a probability smaller than 0.05 . Thus it figures that welfare influences organizational performance in the Aceh Financial Management Agency.

\section{H6 is accepted :the effect of self efficacyon organizational performance}

Estimated parameter value for testing the effect ofself efficacy on organizational performance shows the $\mathrm{CR}$ value of 7.857 and with a probability of 0.000 . Both values meet the requirements for $\mathrm{H} 6$ acceptance, namely the $\mathrm{CR}$ value of 7.857 which is greater than 1.97 and a probability smaller than 0.05 . So it describes thatself efficacy influences organizational performance in the Aceh Financial Management Agency

\section{H7 is accepted :The effect of work environment on organizational performance}

Estimated parameter values for testing the effect of work environment on organizational performance shows the $\mathrm{CR}$ value of 3.589 and with a probability of 0.000 . Both values meet the requirements for $\mathrm{H} 7$ acceptance, namely the $\mathrm{CR}$ value of 3.589 which is greater than 1.97 and a probability smaller than 0.05 . So it explains that work environment influences organizational performance in the Aceh Financial Management Agency

\section{CONCLUSION}

The results of causality test in the study prove that welfare has a positive and significant effect on the employee performance, self efficacy has a positive and significant effect on employee performance, work environment has a positive and significant effect on employee performance, employee performance has a positive and significant effect on organizational performance, welfare has a positive and significant effect on organizational performance, self efficacy has a positive and significant effect on organizational performance,and work environment has a positive and significant effect on organizational performance. This research contribute to academic and practical managers that can be set as a reference to formulate both new research model and policies. For academic, this causality tests result is the update of the premises to streghten the further research, and enrich the realm of knowledge. For managers 


\section{International Journal of Business Management and Economic Review}

Vol. 2, No. 06; 2019

ISSN: 2581-4664

especially related managers this is the evaluation result for management that can be used for reregulating the rules in their management to find out the solution for the lack of performance. The limitation in this study lies in the number of variables, and object.

The managerial implication in order to improve the performance of the Aceh Financial Management Agency, the findings formulate some needs to be conducted. From the indicators that show the weak score, it provides the decision that there are theneeds to improve the welfare of employees such as increasing the incentive to employees based on class and length of service, to give more certain responsibilities to employees, to improve the good atmosphere in the employee work environment, and the organization must also make efforts to improve its services to the community. This is the map from the research model that explains the condition of the organization.

\section{REFERENCES}

Bandura, Al. (1993). Perceived Self-Efficacy in Cognitive Development and Functioning. Educational Psychologist, 28(2), 117-148.

Dwiyanto, A. (2012). Reformasi Birokrasi Publik di Indonesia (Cetakan Ke). Yogyakarta: Gadjah Mada University Press.

Ferdinand, A. (2002). Structural equation modeling dalam penelitian manajemen. Semarang: Badan Penerbit Universitas Diponegoro.

Flippo, E. B. (1997). Manajemen personalia ((Alih bahasa: Mohd Mas'ud), ed.). Jakarta: Erlangga.

Ghozali, I. (2018). Aplikasi analisis multivariate dengan program IBM SPSS 25 (9th ed.). Semarang: Badan Penerbit Universitas Diponegoro.

Hariandja, M. T. E., \& Hardiwati, Y. (2002). Manajemen sumber daya manusia: pengadaan, pengembangan, pengkompensasian, dan peningkatan produktivitas pegawai. Jakarta: Gramedia Widiasarana Indonesia (Grasindo).

Hasibuan, M. S. P. (2007). Manajemen Sumber Daya Manusia Perusahaan. Bandung, PT. Bumi Aksa.

Nawawi, H. (2011). Manajemen Sumber Daya Manusia Untuk Bisnis Yang Kompetitif. Yogyakarta: Gadjah Mada University Press.

Rivai, V., \& Sagala, E. J. (2014). Manajemen Sumber Daya Manusia untuk Perusahaan: Dari Teori ke Praktik (3rd ed.). Jakarta: Rajawali Pers.

Robins, S. P., \& Coulter, M. (2012). Management (11th Ed). In Prentice Hall. https://doi.org/10.1002/1521-3773(20010316)40:6<9823::AID-ANIE9823>3.3.CO;2-C

Silvia, P., Maria Luisa, F., Francesco, A., \& Michele, V. (2010). Work Self-Efficacy Scale and Search forWork Self-Efficacy Scale: A Validation Study in Spanish and Italian Cultural Contexts. Revista de Psicología Del Trabajo y de Las Organizaciones, 26(3), 201-210. https://doi.org/10.5093/tr2010v26n3a4

Sujardi. (2009). Pengembangan Kinerja Pelayanan Publik. Bandung: Refika Aditama.

Timpe, A. D. (2012). Seri Manajemen Sumber Daya Manusia 6 : Kinerja = Performance (A. D. Ti, ed.). Jakarta: PT Elex Media Komputindo.

Waldman, D. A., \& Siegel, D. (2008). Defining the socially responsible leader. Leadership Quarterly, 19(1), 117-131. https://doi.org/10.1016/j.leaqua.2007.12.008 